\title{
A környezeti felelősségi irányelv hazai végrehajtásának tapasztalatai, felülvizsgálata, a jövőbeli változtatások iránya
}

\author{
The Observation, Review, and Possible Modification \\ of the EU Environmental Liability Directive in Hungary
}

\begin{abstract}
ABSZTRAKT
A környezeti kárfelelősségröl szóló uniós szekunder jogforrást, azaz a környezeti károk megelözése és felszámolása tekintetében a környezeti felelösségről szóló irányelvet a Tanács és az Európai Parlament közösen alkotta meg 2004-ben. Ugyan többször is módositáson esett át, az irányelv explicit célja a környezeti felelösségre vonatkozó keretrendszer létrehozása a szennyezó fizet elvének alapján, a környezeti károk megelőzése és felszámolása érdekében. A tanulmány áttekinti a 2004-es elfogadása és implementálása utáni legfontosabb hazai jogalkotási lépéseket és a jövőbeli szükséges teendőket is.
\end{abstract}

Kulcsszavak: környezeti felelösség, szennyezö fizet, megelözés, helyreállitás, pénzügyi biztositék

\begin{abstract}
The main secondary legal source of environmental liability in the European Union is the Directive 2004/35/CE of the European Parliament and of the Council of 21 April 2004 on environmental liability with regard to the prevention and remedying of environmental damage. Even though it was modified several times since then, it still remains the basic norm in the environmental field by establishing the regulatory frames by means of the polluter pays principle and the principle of prevention. The present study makes an overview of recent and potential further legislative steps in Hungary with regards to its implementation.
\end{abstract}

Keywords: environmental liability, polluter pays principle, prevention, remedy, financial security

Jelen tanulmány a környezeti károk megelözése és felszámolása tekintetében a környezeti felelősségről szóló 2004-es irányelv hatásait vizsgálja, a hatálybalépés utáni közel másfél évtized tapasztalatait figyelembe véve. A témának különös aktualitást ad, hogy 2020. december 31-ig az Európai Bizottság elé kell tárni valamennyi uniós tagállamnak azon jelentéseket, értékeléseket, amelyek a környezeti kár fogalmának egységes uniós értelmezését segítik elő. Ehhez azonban elengedhetetlen az irányelv jelentőségének áttekintése, e körben a tanulmány vizsgálata elsősorban

\footnotetext{
* Dr. Kecskés Gábor, egyetemi docens, Széchenyi István Egyetem Deák Ferenc Állam- és Jogtudományi Kar; tudományos munkatárs, Társadalomtudományi Kutatóközpont Jogtudományi Intézet; e-mail: kecskesg@ga.sze.hu.
} 
- Magyarország vonatkozásában - a környezeti kár fogalmára, a szennyező fizet elvére és a pénzügyi biztosítékokra, ezek közül is elsődlegesen a környezetvédelmi biztosításra terjed ki.

\section{A környezeti felelősség az Európai Unióban - a 2004/35/EK számú irányelv}

Az Unióban mérföldkőnek számító, a környezeti kárfelelősségröl szóló legfontosabb szekunder norma a környezeti károk megelőzése és felszámolása tekintetében a környezeti felelősségről szóló irányelv, amelyet ${ }^{1}$ a Tanács és az Európai Parlament közösen alkotott meg 2004. április 21-én (és tíz napon belül, április 30-án már hatályba lépett). ${ }^{2} \mathrm{Az}$ irányelv - amelyet 2006-ban, a 2006/21/EK számú irányelv módosított - egyébiránt hároméves periódusban határozza meg az államok számára az implementációs kötelezettség teljesítését, de csak 2010 nyarára (tehát 3 éves késéssel) sikerült azt elérni, hogy valamennyi tagállam implementálja az irányelvet, így a gyakorlatban való alkalmazásáról csak évek múltán áll rendelkezésre elegendő tapasztalat, ezáltal 2020-ban is jobbára csak az elméleti, dogmatikai sajátosságairól való elmélkedés tükrében vizsgálható a norma potenciális hatása, hatékonysága.

Az irányelv explicit célja a környezeti felelősségre vonatkozó keretrendszer létrehozása a szennyező fizet elvének alapján, ${ }^{3}$ a környezeti károk ${ }^{4}$ megelőzése és felszámolása érdekében (1. cikk). Ennek érdekében a felelősségi alakzat meghatározása - túl a szennyező fizet elvének inkább elvi jellegű, mintsem jogi kötelezettségként lefordítható megfogalmazásán - inherens fogalmi elemnek minősül.

Az irányelv alapvetően két területre fókuszál, ahol a felelősség tipológiája szerint egyértelmü differenciálást végez el, amelynek keretében a környezeti kárfelelösségi alakzat tekintetében:

i) egyrészt a fokozott veszéllyel járó tevékenységek esetén az objektív felelösség elvét (ennek megállapításához jogellenes magatartás, bekövetkezett kár és az ezek közötti okozati kapcsolat fennállása szükséges) érvényesíti; ${ }^{5}$

${ }^{1}$ Az irányelv bemutatását lásd: WINTER, Gerd-JANS, Jan-MACRORY, Richard-KRÄMER, Ludwig: Weighing up the EC Environmental Liability Directive. Journal of Environmental Law, Vol. 20, 2008/2, 163-191.

2 Miközben az implementációs határidő az irányelv különböző módokon való, a tagállamok belső jogába történő átültetésre: 2007. április 30. A tagállamoknak 2010 áprilisáig kellett tájékoztatniuk a Bizottságot az irányelv hatásairól, melyet a Bizottság egy jelentésben összegzett 2010 októberében. A jelentés sajnálattal veszi tudomásul a hároméves késlekedést néhány állam részéröl, és azt a következtetést vonja le, hogy emiatt még nem tud érdemben állást foglalni az irányelv hatásáról, ezért a Bizottság - hatékonyságnövelő és az implementációt elősegítő érdemi javaslatokat megfogalmazva - 2014-re halasztotta az irányelv hatásainak felülvizsgálatát. Erröl lásd: Report from the Commission to the Council, the European Parliament, the European Economic and Social Committee and the Committee of the Regions. Under Article 14(2) of Directive 2004/35/CE on the environmental liability with regard to the prevention and remedying of environmental damage. $\operatorname{COM(2010)} 581$ final, Brussels, 12 October 2010. https://eur-lex.europa.eu/LexUriServ/LexUriServ. do?uri=COM:2010:0581:FIN:EN:PDF (2020. 09. 18.).

${ }^{3}$ Az irányelvvel kapcsolatos okozatisági követelményekről és a szennyező fizet elvéről lásd bővebben a hazai szakirodalomból: SulYOK Katalin: Az okozatiság követelményének fontossága a szennyező fizet elv érvényesítésében az uniós és a hazai joggyakorlat tükrében. Közjogi Szemle, 2018/4, 31-39.

${ }^{4}$ Fogalmáról lásd az irányelv 2 . cikkének 1 . bekezdését.

$30 \quad{ }^{5}$ Vesd össze az irányelv 3. cikkének (1) bekezdésével, illetve eme tevékenységeknek a III. számú Mellékletben található felsorolásával. 
ii) másrészt a fokozott veszéllyel nem járó tevékenységek esetében a felróhatóság, a gazdasági szereplő tudati viszonyulása (szándékosság, hanyag gondatlanság) is vizsgálandó, a felelősséget e körben a vétkességi megközelítés uralja. ${ }^{6}$

A kárfelelősséget az irányelv a gazdasági szereplöhöz ${ }^{7}$ telepíti, aki valójában az operátor/üzemeltető (környezethasználó) fogalmával (és tevékenységi körével) azonosítható. Az irányelv tehát a polgári jogi felelősség elvét alkalmazza, és az államtól expressis verbis nem vár el kártérítési-kártalanítási helytállást, amennyiben a gazdasági szereplő nem azonosítható, vagy nem képes az okozott környezeti kárt megtéríteni. Az illetékes hatóságok, azaz végső soron a tagállamok diszkrecionális joga ilyenkor az előállt környezeti kár megtérítéséről való döntés. Természetesen, ha maga az állam vagy állami tulajdonban lévő entitás okozta a kárt, akkor az államnak mint szennyezőnek (vö. a szennyező fizet elvével) kártalanítási kötelezettsége van. E felelősség-kanalizáció azonban továbbra sem minősül az államfelelősség elismerésének, hanem a polgári jogi, tulajdonjogi jogcím alapján megvalósuló felelősség alkalmazásának.

Azt viszont fontos leszögezni, hogy az irányelv 3. cikkének (3) bekezdése szerint a vonatkozó nemzeti jogszabályok sérelme nélkül, az irányelv nem biztosít kártérítési jogot magánszemélyeknek a környezeti kárból vagy az ilyen jellegü közvetlen kárveszélyből következően. A kárfelelösség rezsimjében ugyan mindig kiemelt fontosságot kell tulajdonítani az akár magánszemélyek által is benyújtható kárigényeknek, az irányelv címzettjei azonban a tagállamok, hatálya pedig a környezeti károkra terjed ki, amely inkább az államok, semmint a magánszemélyek szintjén értelmezhető kárfogalom. A környezet sérelme, a környezeti károsodás esetén a joghatóságot gyakorló államhoz kell rendelni a fellépési lehetőségeket. Mivel a magánszemélyekhez füződő egyéb, azaz tradicionális kártípusok (egészségkárosodás, anyagi javakban bekövetkezett károk, veszteségek) nem tartoznak az irányelv hatálya alá, ezért e személyek/entitások kárigénye sem kap szerepet az irányelv vonatkozásában.

\section{Az irányelv legfontosabb elvei}

A szennyező fizet elve mint az irányelv alapvető és látszólag alkalmazható felelősség-keletkeztető tényállása kiemelt figyelmet érdemel. Az elv szerint pénzügyi felelősséggel tartozik az a gazdasági szereplő, akinek tevékenysége vagy mulasztása eredményezte a környezeti kárt. Ha ezt a gondolatot összevetjük az irányelv 5-10. cikkeivel, ${ }^{8}$ akkor kirajzolódik az a részletes processzus, amely a szennyező fizet

\footnotetext{
${ }^{6}$ Voltaképpen itt a negatív definíció elve érvényesül, hiszen az irányelv szövegéből implicit módon az „olvasható" ki, hogy e kategóriába a fokozott veszéllyel járó tevékenységek körébe nem tartozó tevékenységek tartoznak.

${ }^{7}$ A 2. cikkének 6. bekezdése szerint a gazdasági szereplő az „a természetes vagy jogi személyiséggel rendelkező magánszemély vagy közület, aki/amely a keresőtevékenységet végzi vagy irányítja, vagy - amennyiben a nemzeti jogszabályok úgy rendelkeznek - akire az ilyen tevékenység technikai müködtetésével kapcsolatban döntő gazdasági hatáskört ruháztak, ideértve az ilyen tevékenységre felhatalmazással vagy engedéllyel rendelkező vagy az ilyen tevékenység gyakorlására nyilvántartásba vett, vagy azt bejelentő feleket is."

${ }^{8}$ E körben rendelkezik a másodlagos jogforrás a megelőzési és a kárfelszámolási tevékenységröl, valamint ennek költségeiröl, a költségmegosztásról és ennek behajtásának időbeli korlátjáról.
} 
elvének eddigiekben nem tapasztalt mértékü kifejtésében nyilvánul meg. Ebben hozott kardinális változást az irányelv, mely alapján biztosan állítható, hogy a szenynyező fizet elve ma már az uniós acquis communautaire (közösségi vívmányok) hatalmas joganyag szerves részének tekintendö. ${ }^{9}$

Az irányelv a felelősség alóli kimentési okokat meghatározza, ${ }^{10}$ eszerint i) a fegyveres konfliktus, hadiállapot, polgárháború vagy felkelés; illetve ii) a rendkívüli, elkerülhetetlen és kivédhetetlen természeti jelenség miatt előállt károk nem tartoznak az irányelv hatálya alá. A speciális nemzetközi szerződések alkalmazási körébe tartozó tevékenységek folytán, ${ }^{11}$ valamint a honvédelmi és nemzetközi biztonsági célokat, illetve a természeti katasztrófák elleni védelmet szolgáló tevékenységek eredményeként előállt károkra ${ }^{12}$ sem alkalmazható az irányelv. Ezenkívül a tagállamok egyéb, nemzetközi szerződésekben vállalt nemzetközi kötelezettségeit sem érinti az irányelv, ha azok szigorúbban és/vagy átfogóbban szabályozzák az irányelv alkalmazásai körébe tartozó tevékenységek kérdését. Az irányelv 4. cikk (2) bekezdése szerint ugyanis az „irányelv nem alkalmazandó olyan esemény miatt bekövetkező környezeti kár vagy ilyen jellegü közvetlen kárveszély esetén, amelynek tekintetében a felelösség vagy a kártérítés az érintett tagállamban hatályban lévő, a IV. mellékletben felsorolt nemzetközi egyezmények bármelyikének alkalmazási körébe tartozik, beleértve azok jövőbeli módositásait is”. A IV. mellékletben taglalt szerződések közül Magyarország számos ilyen szerződésben részes fél. ${ }^{13}$ Az irányelv 4. cikk (4) bekezdése szerint az irányelv továbbá „nem alkalmazandó az Európai Atomenergia-közösséget létrehozó szerződés hatálya alá tartozó tevékenységek által okozott nukleáris kockázat, környezeti kár vagy ilyen jellegü közvetlen kárveszély, illetve olyan esemény vagy tevékenység esetén, amelynek tekintetében a felelősség vagy a kártérítés az V. mellékletben felsorolt nemzetközi jogi eszközök alkalmazási körébe tartozik, beleértve azok jövőbeli módosításait is". Magyarország részes fél az atomkárokért való polgári jogi felelősségről szóló 1963-as bécsi egyez-

${ }^{9}$ Ezekröl lásd bővebben: DE SMEDT, Kristel: Is Harmonization of Environmental Liability Rules Needed in an Enlarged European Union? Review of European Community and International Environmental Law, Vol. 13, 2004/2, 164-174. https://doi.org/10.1111/j.1467-9388.2004.00394.x; BocKEN, Hubert: Financial Guarantees in the Environmental Liability Directive: Next Time Better. European Energy and Environmental Law Review, Vol. 15, 2006/1, 13-32. DOI: 10.3233/EPL-1997-27419; HINTEREGGER, Monika (ed.): Environmental Liability and Ecological Damage in European Law. Cambridge University Press, Cambridge, 2008, Ixviii + 697.; Bergkamp, Lucas-Goldsmith, Barbara (eds): Environmental Liability Directive - A Commentary. Oxford University Press, Oxford, 2013, 408. és Josefsson, Henrik: The Environmental Liability Directive, the Water Framework Directive and the Definition of Water Damage. Environmental Law Review, Vol. 20, 2018/3, 151162. https://doi.org/10.1177/1461452918789814.

10 Lásd az irányelv 4 . cikkét.

11 Lásd az irányelv 4. cikkének (2)-(4) bekezdéseit, valamint a IV. számú Mellékletet.

12 Lásd az irányelv 4 . cikkének (6) bekezdését.

13 Így például az olajszennyezéssel okozott károkkal kapcsolatos polgári jogi felelősségről szóló 1992-es egyezményben és az olajszennyezéssel okozott károk megtérítésére létesítendő nemzetközi alap létrehozásáról szóló 1992-es egyezményben. L. 2007. évi IX. törvény az olajszennyezéssel okozott károk megtérítésére szolgáló nemzetközi alap létrehozataláról szóló 1992. évi egyezmény és az olajszennyezéssel okozott károk megtérítésére szolgáló nemzetközi alap létrehozataláról szóló 1992. évi egyezményhez elfogadott 2003. évi jegyzőkönyv, valamint az olajszennyezéssel okozott károkkal kapcsolatos polgári jogi felelősségről szóló 1992. évi egyezmény kihirdetéséről. 
ményben, ${ }^{14}$ valamint az atomenergia területén való polgári jogi felelősségről szóló 1960-as Párizsi Egyezmény és az 1963-as bécsi egyezmény végrehajtásáról szóló közös jegyzőkönyvben ${ }^{15}$ is.

A környezeti felelösség nemzetközi jogi alapvetései egyébiránt visszaköszönnek az irányelvben is, talán egy markáns kivétellel, ugyanis az irányelv maga nem biztosít perlési lehetőséget a károsult magánszemélynek, noha természetesen a belső jogok alapján ezek a lehetőségek minden bizonnyal adottak a sérelmet szenvedett fél számára. A nemzetközi környezeti felelösség alappillérei viszont hasonlóak, hiszen a felelősségről szóló szerződések vétkességi alapú és korlátozott, széles körü kimentési okokkal körülbástyázott civiljogi (azaz nem állami) felelősség elvét nevesítik. Ezek a szerződések leginkább az operátor/engedélyes, azaz a potenciálisan szennyező tevékenységet folytató gazdasági társaság felelősségét rögzítik, többnyire időbeli korlátokat felállítva (alacsony elévülési idővel). Ezen kívül pedig a kárfogalom „visszafogott” definiálása is állandó kritikák tárgyát képezi, így például a környezeti helyreállító intézkedések költségei gyakorta kimaradnak a kárfogalom hatálya alól. Azonban a szennyező fizet elve, a megelőzés kötelezettsége és az engedélyes, azaz potenciális szennyező perelhetősége szinte valamennyi ilyen nemzetközi szerződés közös elemét alkotja.

A megelözés kötelezettsége (5. cikk) és a tagállamok közötti együttmüködés (15. cikk) alapelvi szinten van jelen az irányelvben - hasonlóan számos nemzetközi szerződéshez -, míg a pénzügyi biztosítékok (14. cikk) kívánatos, de nem kötelező rendszere eltér a szerződésekben alkalmazott metódustól, ahol ezt kötelezettségként írják elö. A biztosítékok létrehozását az irányelv a tagállamok hatáskörébe utalja, nemzetközi pénzügyi alapot így nem hozva létre.

Az időbeli hatály kérdése kapcsán a 2007. április 30-i hatálybalépés előtt bekövetkezett károkra az irányelv nem alkalmazható, amennyiben olyan meghatározott tevékenység eredményeként került sor azokra, amely a fent említett időpont előtt zajlott, és ezen időpont előtt befejeződött. Az irányelv tehát a hatálybalépést követöen bekövetkezett kibocsátás, esemény vagy incidens által okozott károkra vonatkozik, amennyiben a károk

i) ezen időpontot követően gyakorolt tevékenységekből származnak; vagy

ii) ezen időpontot megelőzően gyakorolt, azonban az említett időpont lejártakor még be nem fejeződött tevékenységekböl származnak.

Az irányelv ismeri az objektív elévülési határidőt is, amelyet a károkozó kibocsátás, esemény vagy incidens bekövetkezésétől számított 30 évben határoz meg. ${ }^{16}$

Összességében elmondható, hogy az irányelvnek az adott területhez való „hozzáadott értéke" több síkon is szemléltethetö, mi több, elismerésre méltó, és egyfajta kvázi-kódexként minősíthető az adott területen. Egyrészt egy sui generis entitás kör-

\footnotetext{
${ }^{14}$ 24/1990. (II. 7.) MT rendelet az atomkárokért való polgári jogi felelősségről Bécsben 1963. május 21-én kelt nemzetközi egyezmény kihirdetéséröl.

15 130/1992. (IX. 3.) Korm. rendelet az atomkárokért való polgári jogi felelősségröl szóló Bécsi Egyezmény és az atomenergia területén való polgári jogi felelősségről szóló Párizsi Egyezmény alkalmazásáról szóló, 1989. szeptember 20-án aláirt közös jegyzőkönyv kihirdetéséről.

${ }^{16}$ Vesd össze az irányelv 17 . és 19 . cikkeit.
} 
nyezeti kárfelelősségi irányait határozta meg első alkalommal. Másrészt az explicit környezeti kárfelelősség - kiemelve a hatálya alól az egyéb kártípusokat - elméletére és gyakorlati megvalósítására nem találunk példát a nemzetközi jog terrénumában sem, így ez nóvumként hat, és egyfajta zsinórmértékül szolgálhat a hasonló tárgyú későbbi jogalkotási törekvések számára is. Harmadrészt hosszasan kifejti a másodlagos jogforrás a szennyező fizet elvének jogias, az elvek szintjén történő meghatározását meghaladó, jogi kötelezettségek nyelvén is értelmezhető inherens elemeit, amelyeket egyéb normákban hiába keresnénk. Negyedrészt a felelősségi alakzatok szándékolt és egyértelmű megkettőzése irányadó és célravezető megoldás lehet bizonyos összetett tevékenységi kör (amikor egy adott norma hatálya alá tartozó tevékenységek között egyaránt megtaláljuk a fokozott veszéllyel járó és az egyéb tevékenységeket is) szabályozásakor. Végül, de nem utolsósorban az irányelv nem akadályozza meg a tagállamokat abban, hogy szigorúbb rendelkezéseket hozzanak a környezeti károk megelőzésével vagy felszámolásával kapcsolatban (a szubszidiaritás elvének megnyilvánulására utaló példaként hozható tehát fel).

E körben említhető a Magyarországot érintő, Túrkevei Tejtermelő Kft. mint felperes által indított ügy az Európai Bíróság előtt, amelyben a Bíróság úgy foglalt állás, hogy a felperes által vitatott, a tulajdonában álló ingatlanon történt, jogellenes és levegőszennyező hulladékégetés miatt kiszabott bírság jogszerü lehet, ha a nemzeti bíróság „a jogellenes környezetszennyezés helye szerinti telkeket használó gazdasági szereplőkkel együtt egy másik személyi körnek, azaz az említett telkek tulajdonosainak egyetemleges felelősségét is megállapítja az ilyen környezeti kár okozása miatt, anélkül hogy előírná a tulajdonosok magatartása és a megállapított kár között fennálló okozati összefüggés bizonyítását, feltéve hogy e szabályozás összeegyeztethető az uniós jog általános elveivel”. Ez esetben tehát a nemzeti hatóság, jelen esetben az Országos Környezetvédelmi és Természetvédelmi Főfelügyelőség „bírságot is kiszabhat (...), feltéve hogy az ilyen szabályozás alkalmas arra, hogy elősegítse a szigorúbb védelmi cél elérését, és a bírság összegének meghatározására vonatkozó részletes szabályok nem haladják meg az e cél eléréséhez szükséges mértéket, amit a nemzeti bíróságnak kell vizsgálnia". ${ }^{17} \mathrm{~A}$ döntés értelmében a tagállamok irányelvben foglaltaknál szigorúbb szabályozási és jogalkalmazási mozgástere tehát általában lehetséges, amennyiben az összhangban van az uniós joggal.

\section{Az irányelv átültetése Magyarországon}

A 2007. április 30-i implementációs határidőre Lettország, Litvánia, Magyarország és Olaszország ültette át az irányelvet, de 2010-re már valamennyi állam elvégezte átültetési kötelezettségét.

Az irányelv hazai átültetése tulajdonképpen egy 2007-es implementációs hullámot és egy ezt követő kisebb, sporadikus jellegű módosításokat jelentett 2015-ig.

17 C-129/16. sz., Túrkevei Tejtermelö Kft. kontra Országos Környezetvédelmi és Természetvédelmi Főfelügyelöség c. ügyben 2017. július 13-án hozott ítélet (ECLI:EU:C:2017:547). 
A 2007-ig tartó első nagy harmonizációs hullámban, módosítások révén az irányelvvel való megfeleltetésre került - csak a legfontosabbakat kiemelve:

- a környezet védelmének általános szabályairól szóló 1995. évi LIII. törvény (a továbbiakban: Kvt.), 18

- a vízgazdálkodásról szóló 1995. évi LVII. törvény,

- a természet védelméröl szóló 1996. évi LIII. törvény, valamint a kormányrendeletek közül

- a 90/2007. (IV. 26.) Korm. rendelet a környezetkárosodás megelőzésének és elhárításának rendjéről,

- a 91/2007. (IV. 26.) Korm. rendelet a természetben okozott károsodás mértékének megállapításáról, valamint a kármentesítés szabályairól,

- a 92/2007. (IV. 26.) Korm. rendelet a felszín alatti vizek védelméről szóló 219/2004. (VII. 21.) Korm. rendelet módosításáról, illetve

- a 93/2007. (IV. 26.) Korm. rendelet a felszíni vizek minősége védelmének szabályairól.

A 2007-et követő, 2015-ig elvégzett kisebb és sporadikus, nem átfogó módosítások azonban már inkább csak az irányelvben foglalt egyes elvárásokra fókuszáló implementációs megoldások. Ezek következtében a Polgári Törvénykönyv (2013. évi V. törvény) megfelel a környezeti felelösségi irányelvnek (figyelembe véve azt is, hogy az irányelv nem a magánszemélyek polgári jogi kártérítési jogosultságáról szól), ${ }^{19}$ míg a hulladékról szóló 2012. évi CLXXXV. törvény vagy a bányászatról szóló 1993. évi XLVIIII. törvény módosítása, illetve a vízvédelmi igazgatási feladatokat ellátó szervek kijelöléséröl és egyes vízügyi tárgyú kormányrendeletek módosításáról szóló 366/2015. (XII. 2.) Korm. rendelet a környezeti felelősségi irányelvnek való megfelelést szolgálják egyes részletszabályok megállapítása révén.

\section{Az irányelv felülvizsgálata, hazai végrehajtásának tapasztalatai}

Egy éven belül, 2005-ben a szektorális érdekek miatt került publikálásra a Tanács és az Európai Parlament közös 2005/35/EK számú irányelve a hajók által okozott szennyezésről és a jogsértésekre alkalmazandó szankciók bevezetéséről, amely a felelősségi jog területének egy speciális szegmensét, a szankcionálás jogintézményét taglalja. Az irányelv módosítását példaértékủ gyorsasággal végezték el, amikor egyrészt a 2006/21/EK számú irányelvvel a Tanács és az Európai Parlament az ásványinyersanyag-kitermelő iparban keletkező hulladék kérdését a 2004/35/ EK számú irányelv alkalmazási körébe vonja, amely a módosított 2004-es irányelv

\footnotetext{
${ }^{18}$ A Kvt. felelősségi jogi vonatkozásairól a hazai szakirodalomból lásd bővebben: BöGös Fruzsina: A környezetvédelmi törvény 102. §-ának értelmezése a 2004/35/EK irányelv rendelkezései tükrében. Közjogi Szemle, 2018/4. 21-30.

${ }^{19}$ A Ptk. ezt kifejezetten nem említi, ugyanakkor - hasonlóan a régi, 1959. évi IV. törvényhez, annak 345. §-ához a veszélyes üzemi felelősség szabályai szerint felel az is, aki az emberi környezetet veszélyeztető tevékenységével másnak kárt okoz (Ptk. 6:535. §). Ez a szövegezés kétségkívül megfelel a környezeti felelösségi irányelvnek is.
} 
környezetjogi relevanciáját kétségtelenül bizonyítja, és alátámasztja. A jogalkotók helyesen ismerték fel annak lehetőségét, hogy az általános környezeti kárfelelösségi irányelv hatálya alá utólag bevonható szennyezési tevékenységek és kártípusok a terület egységesedését, valamint a kárfelelősségi irányelv hatékonyabbá tételét, ezáltal pedig az Unió kárfelelősségi törekvéseit hatékonyan szolgálják. Másrészt a 2005/35/EK számú irányelv 2009-es módosítása (2009/123/EK számú irányelv) az uniós jogalkotás és döntéshozatal gyorsaságát és reagálási képességét is szintén jól mutatja. Ez - még, ha messze vezethet is e gondolat - annak bemutatására teljesen alkalmas, hogy az államok mennyire érzékenyek a környezeti károkkal, veszteségekkel kapcsolatos ügyek kezelésére, amely felismerés egy gyors, problémakövető jogalkotást lehetővé tevő jogszabályi és intézményi háttérrel együtt már optimális és hatékony rendezési módokat jelöl ki.

A környezeti típusú irányelvek gyakorlatban történő alkalmazásának és az egyes irányelvek értelmezésének kérdéséröl egy elöremutató ítélet született 2010-ben, az ún. ERG-ügyben (C-378/08), ${ }^{20}$ amikor az Európai Bíróság Nagykamarája ítéletében kifejtette, hogy amennyiben valamely környezeti szennyezés esetében a környezeti károk megelőzése és felszámolása tekintetében a környezeti felelősségről szóló 2004/35/EK irányelv alkalmazása időbeli és/vagy tárgyi hatályának a feltételei nem teljesülnek, az ilyen helyzet a Szerződés szabályainak tiszteletben tartása mellett és a másodlagos jog más aktusainak a sérelme nélkül a nemzeti jog hatálya alá tartozik. ${ }^{21} \mathrm{~A}$ szennyező fizet elve kapcsán az ítélet szerint önmagában a környezeti kárfelelősségi tárgyú irányelvvel „nem ellentétes az olyan nemzeti szabályozás, amely lehetővé teszi az illetékes hatóság számára, hogy ezen irányelv keretében eljárva vélelmezze a gazdasági szereplők és a megállapított szennyezés közötti okozati összefüggés ${ }^{22}$ (a vélelem alapját képező hiteles tényekkel ugyanakkor rendelkeznie kell a hatóságnak - a szerző) fennállását azon tényből kifolyólag, hogy a létesítményeik az említett szennyezés területének közelében találhatók". ${ }^{23}$

Bizonyos esetekben elfogadott az is, hogy az illetékes hatóság - az irányelv hatálya alá tartozó gazdasági szereplők számára - a környezeti károk felszámolására irányuló intézkedéseket írjon elő, vétkességre, gondatlanságra és szándékosságra tekintet nélkül. Másrészről azonban az illetékes hatóságnak a bizonyítást szabályozó nemzeti rendelkezések alapján okozati összefüggést kell megállapítania a felszámolási intézkedésekkel érintett gazdasági szereplők tevékenysége és e szennyezés között.

${ }^{20} \mathrm{Az}$ ügy tárgya egy előzetes döntéshozatal iránti kérelem volt, amelyben a szennyező fizet elve játszott jelentős szerepet, olyan nemzeti szabályozás vonatkozásában, amely a közigazgatási szervre ruházza azt a hatáskört, hogy a szennyezés felelősének meghatározása céljából végzett vizsgálat nélkül magánvállalkozásokra terhelje a felszámolási intézkedések végrehajtását. Case C-378/08, Raffinerie Mediterranee (ERG) SpA and Others v. Ministero dello Sviluppo economico and Others, Judgment of the Court (Grand Chamber) of 9 March 2010, ECLI:EU:C:2010:126.

${ }^{21}$ Lásd Case C-378/08 (ítélet) 70. szakasz.

22 Erről lásd bővebben: Mossoux, Youri: Causation in the Polluter Pays Principle. European Energy and Environmental Law Review, Vol. 19, 2010/6, 279-294.

${ }^{23}$ Lásd Case C-378/08 (ítélet) 56. szakasz. 
Az irányelv további utóélete kapcsán megemlíthető, hogy 2016-ban egy végrehajtást összegző jelentés ${ }^{24}$ megvizsgálta az irányelv 2007 és 2013 közötti végrehajtásának eredményeit, valamint tartalmazott egy, az ún. REFIT (a Bizottság célravezető és hatásos szabályozás programja - Regulatory Fitness and Performance Programme) keretén belül elvégzett értékelést is. A jelentés szerint tagállami szinten, így pedig összeurópai szinten is jelentős elörehaladás történt egyes környezeti károk felszámolása és megelőzése vonatkozásában. Ugyanakkor a REFIT felsorolja „az irányelv hatásának különbségeit okozó további tényezők” körét, amelyek vonatkozásában megemlíti az irányelv hatálya alá eső káresetek nyilvántartásának egységesítési törekvését, valamint a nyilvánosság részvételének és bevonásának szükségességét.

A jelentés konkrétabban már kitér arra is, hogy:

- „Nagyobb figyelmet kell fordítani a »jelentős kár« és a »kedvező védettségi állapot« fogalmaknak a két irányelvben található meghatározásaira, tekintettel a jelentős kár küszöbértékének egyfelől a környezeti felelősségről szóló irányelven, másfelől a természetes élőhelyekről szóló irányelv 6. cikkének (2) bekezdésén belül esetlegesen eltérő jelentésére és/vagy alkalmazására.

- A »jelentős kár« küszöbértékét következetesebben kell alkalmazni, és egyértelmúbben meg kell azt határozni. Ezt számos illetékes hatóság és a biztosítási ágazat is jelezte.

- A környezeti felelősségről szóló irányelvben problematikusnak bizonyultak a »kedvező védettségi állapot« fogalom esetén alkalmazott földrajzi hivatkozások (európai terület, egyes tagállamok területe, természetes kiterjedés). Ezért tisztázni kell, hogy az irányelv helyes és hatékony végrehajtása érdekében helyszínekhez kötött megközelítésre van szükség.

- A biológiai sokféleségben okozott károk jelentőssé válását gátló intézkedéseket gyakran nem hozzák meg, méghozzá azon helytelen feltételezés alapján, hogy csak akkor lehet megelőző intézkedéseket hozni, ha tudni lehet, hogy a kár jelentőssé fog válni."

Egy évvel később, egy többéves munkaprogram (Multi-Annual Work Programme 2017-2020 - Making the Environmental Liability Directive more fit for purpose) került elfogadásra a REFIT-re való reakcióként, a tagállami kormányzatokat segítendő, konzultatív jelleggel. Ennek értelmében a Bizottság a munkaprogram három markáns pillérének kiemelésével gondolta el az irányelv céljainak megvalósítását. A munkaprogram első elvárásai között szerepel az értékelésnél és döntéshozatalnál elengedhetetlenül fontos adatok megbízható szolgáltatása a Bizottság felé minden érintett szereplő részéről. A második pillér alapján hatékonyabb végrehajtást

${ }^{24}$ A Bizottság jelentése a Tanácsnak és az Európai Parlamentnek a környezeti károk megelőzése és felszámolása tekintetében a környezeti felelősségröl szóló 2004/35/EK irányelv 18. cikkének (2) bekezdése alapján. COM/2016/0204 final. https://eur-lex.europa.eu/legal-content/HU/TXT/PDF/?uri=CELEX:52016DC0204\&fr om=HU (2020. 09. 15.). Ezenkívül ugyanebben az évben az Európai Parlament határozatot fogadott el a környezeti felelősségi irányelv végrehajtásáról (2016 Resolution of the European Parliament on the Implementation of the Environmental Liability Directive). https://www.europarl.europa.eu/doceo/document/ TA-8-2017-0414_EN.html (2020. 09. 25.). 
szolgáló eszközöket és intézkedéseket kell foganatosítani tagállami részröl, míg a harmadik pillér szerint a pénzügyi biztosítékok rendszerét, rendelkezésre állását és folyósíthatóságát kell tagállami részröl garantálni. ${ }^{25}$

2018-ban kezdte el megszövegezni a Bizottság az Improving financial security in the context of the Environmental Liability Directive elnevezésü dokumentumot, amelyet végül 2020 májusában fejeztek be, és tagállami, valamint uniós szinten a pénzügyi biztosítékokról ad áttekintő elemzést.

Az irányelvet 2019-ben az (EU) 2019/1010 rendelet újonnan módosította, immáron összehangolva és egyszerüsítve a tagállamok környezeti jogszabályok terén érvényes jelentéstételi kötelezettségeit. A 2019. június 26. óta hatályos új szabályok szerint a tagállamok jelentést tesznek a Bizottságnak az irányelv végrehajtása során szerzett tapasztalatokról. ${ }^{26}$ Ezenkívül a Bizottság 2023. április 30-ig, ezt követöen pedig 5 évenként közzéteszi az irányelvröl az uniós országok által szolgáltatott információk alapján készített jelentését, értékelését. A Bizottság feladatául szabja továbbá 2020. december 31-ig, hogy iránymutatást dolgozzon ki a „környezeti kár” fogalmának közös, uniós szintű értelmezéséröl.

A fenti változások valószínűsíthetően jelentősen befolyásolják majd az irányelv nemzeti szintü végrehajtását, mivel az irányelv gyakorlati alkalmazásának több mint másfél évtizedes tapasztalatainak beépitésére is alkalmasak lesznek.

Magyarország vonatkozásában több elemzés és jelentés kitér arra, hogy pénzügyi biztosítékok 4 biztosítótársaságnál elviekben adottak a környezeti felelősségi irányelv rendelkezéseinek megfelelően, de ez ugyanakkor hazánkban nem általánosan kötelező jellegű, kivéve a természet védelméről szóló törvény 2005-ös és 2008as módosításait, amely azonban még nem elegendö, több környezeti vonatkozású jogszabályban ezt rögzíteni kellene. A jövőre nézve érdemes azt is megfogalmazni, hogy Magyarország nem hozott létre pénzügyi alapot a környezeti kár megelőzésének és helyreállításának költségeire azon esetekre vonatkozóan, ha a felelös fél nem tud fizetni, vagy nem deríthető fel a kiléte. ${ }^{27}$

További Magyarország-specifikus felvetésként fogalmazódott meg, hogy a környezetvédelmi biztosítási piac/szektor kicsi, és ebböl (is) következően az ingatlanbiztosítások esetén a biztosítási szerződésekbe és általános szerződési feltételekbe foglalt környezeti klauzulák már nem elégségesek, a környezeti károk rendezése érdekében konkrétabb, egyértelmübb rendelkezésekre van szükség. ${ }^{28}$

Az önálló környezetvédelmi biztosítás intézménye is kiegészítésre szorul, mert ez hazánkban csak korlátozott, főként a csak balesetből eredő szennyezésre kor-

${ }^{25} \mathrm{~A}$ hazai szakirodalomban Csák Csilla részletesen elemzi a környezeti pénzügyi biztosítékok rendszerét. Lásd Csák Csilla: A környezetjogi felelösség magánjogi dogmatikája. Miskolci Egyetem, Miskolc, 2012, 183-204.

${ }^{26}$ A szolgáltatandó információk köre az irányelv VI. mellékletében szerepel, és 2022. április 30-ig, majd ezt követően ötévente kell begyüjteni azokat a tagállamoknak, majd a Bizottság elé tárni.

${ }^{27}$ Annex II, Member State Summaries Improving financial security in the context of the Environmental Liability Directive No 07.0203/2018/789239/SER/ENV.E.4 May 2020 Final. https://ec.europa.eu/environment/legal/ liability/pdf/Final_report.pdf (2020. 09. 17.).

${ }^{28}$ Annex I, Hungary Improving financial security in the context of the Environmental Liability Directive No 07.0203/2018/789239/SER/ENV.E.4 May 2020. https://ec.europa.eu/environment/legal/liability/pdf/Final_ report.pdf (2020. 09. 17.). 
látozódik; ezek a biztosítási konstrukciók főszabály szerint nem számolnak például a „rendes” müködés eredményeként bekövetkező környezeti kárral, környezeti terheléssel. ${ }^{29}$

A környezetvédelmi törvény 101. §-a szerint a környezethasználó (külön kormányrendeletben meghatározott tevékenységéhez) környezetvédelmi biztositék adására köteles, továbbá a tevékenységével okozható előre nem látható környezetkárosodások felszámolása finanszírozásának biztosítása érdekében környezetvédelmi biztositás kötésére kötelezhető. A környezethasználó az általa okozott környezetkárosodásért helytállni és a megelőzési, illetve helyreállitási költségeket viselni, és egy 2020-as módosítás ${ }^{30}$ szerint ennek „elmaradása vagy eredménytelensége esetén a környezetvédelmi hatóság, vagy a más hatóság által engedélyezett tevékenység esetén a környezetvédelmi hatóság megkeresésére az engedélyező hatóság, illetve a bíróság (...) a környezetveszélyeztető, illetve környezetkárosító tevékenység folytatását korlátozza, az általa megállapított feltételek biztosításáig felfüggeszti vagy megtiltja". Ez a módosítás már jobban megfelel a környezeti felelősségi irányelv elvárásainak.

A természet védelméről szóló 1996. évi LIII. törvény a 73. §-ban (Biztosíték és biztosítás) a 2005-ös és 2008-as módosítások révén leszögezi, miszerint, aki a természeti érték állagára, állapotára veszélyt jelentő tevékenységet folytat, illetve védett természeti területen, valamint európai közösségi jelentőségü természetvédelmi rendeltetésű területen veszélyes anyagot használ, külön kormányrendeletben meghatározott biztosíték adására köteles. Ezenkívül a környezethasználó, aki tevékenységével okozható előre nem látható természeti károk felszámolása finanszírozásának biztosítása érdekében környezetvédelmi biztositás kötésére kötelezhetö. Fontos megjegyezni, hogy az ilyen, a környezeti felelősségi irányelvnek megfelelö pénzügyi biztosítékok részletes szabályairól szóló kormányrendelet eleddig nem jött létre, ez tehát a hazai jogharmonizáció vizsgálatát illetően komoly hiányosságként mutatkozik. Az előbbiekben taglalt két fö ágazati törvényhez képest két másik ágazatban azonban a jogalkotó már korábban lépett, és a törvény kisebb módosításával, valamint kormányrendelet elfogadásával tette hatékonyabbá a pénzügyi biztosítékok szerepét a környezeti felelősség ágazati normáiban. Egyrészről a bányászatról szóló 1993. évi XLVIII. törvény módosítása után már a 41. § (7) bekezdésében úgy fogalmaz, hogy „a bányavállalkozó bányászati tevékenységből eredő kötelezettségei teljesitésének pénzügyi fedezetére a miniszter a koncessziós szerződésben, a bányafelügyelet az engedélyben a bányavállalkozó ajánlata figyelembevételével biztositási szerződés megkötését vagy biztosíték adását írja elő. E pénzügyi fedezetnek ki kell terjednie a bányakárok megtéritésére, valamint a tájrendezési kötelezettség teljesitésére - ideértve a hulladékkezelö létesítmények környezeti kárait és rehabilitációs munkálatait - is". Másrészről a hulladékról szóló 2012. évi CLXXXV. törvény vonatkozásában elmondható, hogy e tárgyban már hatályba lépett egy olyan

\footnotetext{
${ }^{29}$ Annex III, Environmental Insurance: Availability and Demand Improving financial security in the context of the Environmental Liability Directive No 07.0203/2018/789239/SER/ENV.E.4 May 2020 Final. https://ec.europa. eu/environment/legal/liability/pdf/Final_report.pdf (2020.09. 17.).

${ }^{30}$ Lásd 2020. évi LI. törvény.
} 
kormányrendelet, amely egyes vagyoni biztosítékokra vonatkozóan részletes szabályokat is tartalmaz, noha az elektromos és elektronikus berendezésekkel kapcsolatos hulladékgazdálkodási tevékenységekről szóló 197/2014. (VIII. 1.) Korm. rendeletben szabályozott gyártó biztosítékadási kötelezettsége, illetve ennek mértékének és számításának módja korántsem tekinthető általános környezetvédelmi érdekünek. A kormányrendelet 14. § (1) bekezdése szerint ugyanis környezetvédelmi biztosítás csak egy a lehetséges vagyoni biztosítéki típusok közül. Ezenkívül a környezeti hatásvizsgálati és az egységes környezethasználati engedélyezési eljárásról szóló 314/2005. (XII. 25.) Korm. rendelet is - az irányelvvel való megfelelést szolgálva - a biztosítékadási és céltartalék képzéssel kapcsolatos teendőkre nézve külön szabályait teszi szükségessé.

Amíg tehát a környezetvédelmi és a természet védelméről szóló törvény szerint a kormányrendelet elfogadása még várat magára a pénzügyi biztosítékok kielégítő rendezéséröl, addig a bányászati törvény módosítása és a hulladékokról szóló törvényhez kapcsolt kormányrendelet révén utóbbi ágazatban Magyarország megfelelni látszik az uniós környezeti felelősségi direktíva pénzügyi biztosítékadási elvárásának.

\section{Konklúzió}

Az irányelv hazai átültetése és végrehajtása vonatkozásában elmondható, hogy Magyarország uniós szinten is példaértékű módon, az irányelvben előirt határidőre implementálta a környezeti felelősségi direktívát. Az első, 2007-es implementációs hullám révén elsődlegesen a fő ágazati szabályban, a környezet védelméről szóló törvényben vezette át a jogalkotó azokat a módosításokat, amelyek közvetlenül az irányelvben foglaltaknak való megfelelést szolgálják. A fejlesztési lehetőségek közül - a fentiekkel összhangban - azonban még számos tennivaló akad, túl azon, hogy Magyarországnak mint tagállamnak rendszeresen jelentéseket, értékeléseket kell a Bizottság elé tárnia, és a környezeti kár fogalmának egységes uniós értelmezéséről kell segítséget nyújtania a Bizottságnak 2020. december 31-ig. Nem kétséges ugyanakkor az sem, hogy a környezetvédelmi biztosítékok átfogó rendezésére szükség volna egy kormányrendeletben (ahogyan azt több törvény is előírja hazánkban).

A fentiekben taglalt ún. REFIT szerinti elvárások körébe sorolható továbbá az irányelv szerinti jelentős kár, jelentős kockázat, jelentős kedvezőtlen hatás fogalmainak - lehetőség szerinti - pontosítása, amelyek jelenlegi, igencsak általános megfogalmazásuk tükrében széles körü és diszkrecionális értelmezési tartományt nyújtanak a tagállamoknak, amely megnehezíti a kárfogalom és káresemények egységes kezelését uniós szinten. A REFIT megállapítások szerint az igen általános fogalommeghatározások (itt kifejezetten a ,jelentős kár” küszöbértékére hivatkozik a REFIT) értelmezése bizonytalanságot szülhet, ezenkívül

„nem megfelelően alkalmazzák a kiegészítő és kompenzációs felszámolást, valamint hogy nem áll rendelkezésre elégséges adat a környezeti károkról, a kárfelszámolási esetekről és költségekröl. A tagállamok között a jelentett esetek számában és tartalmában mutatkozó szignifikáns eltérések részben az irányelvnek ezekre az 
aspektusaira és összefüggéseire vezethetök vissza, de a szignifikáns eltérések fő okainak a »jelentős kár « küszöbértékének különböző alkalmazása és a már korábban érvényes nemzeti keretrendszerek különbségei bizonyultak." ${ }^{31}$

Azonban a fentiekben taglalt 2020. december 31-ig kialakítandó közös értelmezési keret a környezeti kár fogalmáról megoldást jelenthet ezekre az anomáliákra, bizonytalanságokra. Eme értelmezési keret kialakításához pedig valamennyi uniós tagállam - köztük Magyarország - együttmüködése és támogatása szükséges.

31 A Bizottság jelentése a Tanácsnak és az Európai Parlamentnek a környezeti károk megelőzése és felszámolása tekintetében a környezeti felelősségről szóló 2004/35/EK irányelv 18. cikkének (2) bekezdése alapján \{SWD(2016) 121 final\} \{SWD(2016) 122 final. https://eur-lex.europa.eu/legal-content/HU/TXT/PDF/?uri=C ELEX:52016DC0204\&from=HU (2020. 09. 15.). 